\title{
An Economic Assessment Model of Employment Dynamics, Capacity Development and Household Telecommunication Expenditure in Nigeria
}

\author{
Eke, Chukwuemeka Ifegwu ${ }^{1 *} \quad$ Magaji, Sule $^{1} \quad$ Augustine Olorunfemi Obalemo $^{2}$ \\ Ezeigwe, Grace Chinyere ${ }^{3}$
}

1.Department of Economics, Faculty of Social Sciences, University of Abuja, PMB 117, Abuja, Nigeria

2.Faculty of Business Administration, Department of Management, Nile University of Nigeria, Abuja, Nigeria

3.Department of Management science, Faculty of Management sciences, Nile University of Nigeria, Abuja,

Nigeria

\begin{abstract}
This article emphasizes the use of mathematical logic in scientifically examining and explaining the economic challenge of massive youth employment crisis, under capacity development and unbridled household consumption of telecommunication services. The proposed model is called GSM-EMCAD. The major finding of the paper is that training or capacity development in telecommunication is a key factor that can expand employment opportunities in this $21^{\text {st }}$ century and beyond, implying that youth employment and loss of growth opportunities in Nigeria can be explained by the rapid innovation in global system for mobile telecommunication and the mismatch between market realities and labour skills set as opposed to many other factors highlighted in literature. The motivation is that in a knowledge-based economy, the spillover effects from investment in GSM telecommunication and people keep generating returns. Examples are GSM telecommunications hardware and software, and other high-tech industries, play a particularly important role here.
\end{abstract}

Keywords: Telecommunication, Employment and Labour

JEL Classification 014

DOI: $10.7176 / \mathrm{JESD} / 11-4-12$

Publication date: February $29^{\text {th }} 2020$

\section{Introduction}

Over the past ten decades Nigeria has witnessed a massive disequilibrium in the labour markets, economic recession and spike in household telecommunication consumption. For example, between 1999 and 2010 the economy witnessed substantial growth occasioned by diffusion of Global System Mobile telecommunication among other factors. This trend culminated in the rebasing of its Gross Domestic Product matrix from about $\$ 270$ to $\$ 510$ billion in 2013. However, youth unemployment continued to spiral and exacerbated from 2014 to date while productivity growth stagnated. Given such a scenario, it is natural to ask how best to explain it.

An example is the observation that the major shift caused by the advent of global system for mobile telecommunication (GSM Telecom) in Nigeria sometimes in 2000 has triggered some changes two decades down the line, which has affected our social, cultural, and political spheres of our economy. More so, Feyer (2002) argued that improvements in telecommunication technology observed in the early 1990 favoured countries with a more flexible labour market such as the United States of America. Beaudry, Collard and Green (2005) added that this introduction and subsequent diffusion of telecommunication is detrimental to countries with nonflexible, pro-corporate working environment such as Japan. By implication, if Nigeria must experience massive employment generation, capacity development/upgrade, it must as a matter of urgency adopt US style working environment.

In this article, we present a system of equations derived logically based on economic theories on an alternative perspective regarding the haemorrhaging of the Nigerian economy. By extension, our explanation is based on the effects of GSM telecommunication diffusion. We assume the weak posture (or nonexistence) of institutions in explaining the crisis and also emphasises the link between GSM telecom and the labour market. Accordingly, we make two assertions. First, the youth employment crisis experienced in Nigeria is as a result of its maladjustment to GSM telecommunication diffusion in the short run. Secondly, the increasing youth employment crisis is traceable to the inconsistencie0s in the nationally coordinating youth capacity development, focusing their abundant energies to creative endeavours that can provide much needed critical mass for job and economic growth.

This paper is hinged on the endogenous growth theory which explains that growth is generated from within an economic system as a result of certain internal processes. For instance, the enhancement of a nation's human capital will lead to economic growth due to new means of production via improvements in technology, efficiency and delivery. The model argued that growth is influenced by internal processes such as human capital, innovation, and investment capital, rather than exogenous theory which emphasizes external, uncontrollable forces, challenging the view of neoclassical economics. In Schumpeterian models, growth basically results from 
technology innovations due to the profit seeking activities of entrepreneurs. Romer (1990) argued that endogenous growth models were informed by neoclassical theory and opined Schumpeterian models highlight the importance of key economic variables such as technology, institutional quality and the degree of financial development. In his submission, Ugur (2016) observed that neoclassical and Schumpeterian models share the common characteristic of being supply-side models. Therefore, improvements in productivity directly generates faster innovation and more investments in human capital.

Initially it may appear unlikely that GSM telecom capacity development or training or skill set upgrade is a key factor in explaining lacklustre performance of Nigeria's economy over the last 25years in terms of youth employment. It is proper to summate that other factors seem most plausible. However, in our opinion capacity development holds sway in explaining the Nigerian crisis. Notwithstanding, since our conjecture regarding the role of GSM telecom capacity development is clearly controversial, we will provide a thorough, surgical and scientific argument based on economic theory, facts, logic and mathematics thereby motivating further country specific and cross country data and regression research to support or refute our claims. In particular, in the first section of the article, we present an introduction into the subject matter and the crux of our mathematical debate. In section 2, we present a model, a concise system of equations outlining our argument on GSM telecom inspired change and Nigeria's maladjustment to its rapid diffusion. Based on the Beaudry and Collard (2004) adjustment process model, it highlights systematic differences in the labour market adjustment matrix induced by new technology adoption. As we discuss, our presentation implies that the role of continuous capacity development plays in affecting the economy takes place at different rates per time.

we will discuss the policy implication of our research bearing in mind the sustainable development goal (SDG) no. 8 which stipulates that:

"inclusive and sustainable economic growth, employment and decent work for all"

And African Union's agenda 2063 which among others prescribes that:

"youth unemployment will be eliminated and Africa's youth guaranteed full access to education, training, skills and technology, health services, Jobs and economic opportunities"

This article builds on previous works aimed at explaining the economics of GSM telecommunication in Nigeria over the years. Initially, Eke and Uke (2006), Eke and Aluko (2006) Magaji and Eke (2013) and Eke (2019) worked on the broad impact GSM telecommunication has on Nigeria's economy and investigated its role during the recessionary years as hypothesized by a larger segment of literature. In these articles, we used models, data, theoretical frameworks and analysis were used to articulate how one can discover the truth and its trends. The results as published in respective journals support the notion that GSM telecom has significant impact on the economy. It is at this point we begin to recognise and question the role GSM telecommunication is playing in our nation's and indeed Africa's youth employment crisis.

This article draws upon some insights we have had from literature, previous work as well as the use of mathematical logic to argue. We will show that GSM telecom capacity development will unlock innovation and job opportunities which appear to have a central role in explaining the crisis ongoing in Nigeria. We must note at this point that our paper is purely a logical effort deploying mathematical economics and therefore solicits implementation and further research.

\section{The Model of GSM telecommunication diffusion}

We present Nigeria as an open economy that produces goods and services, which is either consumed immediately or saved (invested). Our objective with this model is to demonstrate how the advent of GSM telecom triggered structural disequilibrium or disturbance. The inspiration for the model is gotten from Eke (2019), Eke and Mohammed (2012), Magaji and Eke (2013), Beaudry et al (2015)' Beaudry and Collard (2002) and Feyer (2002). We will use the model to demonstrate how GSM telecom using the General Purpose Technology espoused by Bresnahan and Trajtenberg(1995) or Helpmann and Trajtenberg (1998) triggers disruption in the labour market within the context of a population. To advance, we consider Nigeria's economy in two stages. Namely, pre GSM telecommunication and post GSM telecommunication periods. They are discussed in turns.

\section{Nigeria's economy in a pre GSM telecommunication time period}

Consider Nigeria in the pre-2000 with a large pool of households, each of which derives utility from GSM telecommunication consumption over time $\mathrm{K}(\mathrm{t})$ of a typical good or service. Therefore its utility function takes the form:

$$
\mathrm{Z}=\int_{0}^{\infty} e^{-\rho t} \mathrm{Z}[\mathrm{k}(\mathrm{t}) \mathrm{y}(\mathrm{t})] \mathrm{dt}
$$

Where $\rho>0$ is a constant, $Z[K(t)]$ is each household member's utility over time and $y(t)$ is the size of the household income over time.

Assuming

$$
y(t)=n y(t)
$$

It enables the model to operate based on the notion that the size of the household income progresses in the direction of population of Nigeria. In effect, $n>0$ is the constant population rate of growth and $Z(0)>0$ is given 
over time.

Over time each household is assumed to spend inelastically $\mathrm{y}(\mathrm{t})$ unit of naira at the real GSM telecom tariff rate $\mathrm{R}^{0}(\mathrm{t})$. The household possess capital stock $\mathrm{C}^{0}(\mathrm{t})$ and purchases shares at $\mathrm{S}^{0}(\mathrm{t})$. Each household has access to multinational markets via social media and presumably hold treasury bills [T(t)] which is assumed to yield returns equitable to market rate of interest $r$. These revenues are used to make investment $\mathrm{V}^{0}(\mathrm{t})$ and consumption of good and services as a result, the household faces this budget constraint.

$$
\mathrm{T}(\mathrm{t})+\mathrm{K}(\mathrm{t}) \mathrm{y}(\mathrm{t})+\mathrm{V}^{0}(\mathrm{t})=\mathrm{R}^{0}(\mathrm{t}) \mathrm{y}(\mathrm{t})+\mathrm{rT}(\mathrm{t})+\mathrm{S}^{0}(\mathrm{t})
$$

The strategy for household reinvestment becomes

$$
C^{0}(t)=V^{0}(t)-\gamma C^{0}(t)
$$

Where

$$
0 \leq \gamma \leq 1
$$

Which is the rate at which capital depreciates within the system and it is assumed that

$$
\mathrm{C}^{0}(\mathrm{t}) \geq 0 \text { is given }
$$

It is pertinent to note here that it is also assumed that investment made in telecommunication is unidirectional and irreversible. Therefore,

$$
\mathrm{V}^{0}(\mathrm{t}) \geq 0
$$

This means that, each household determines its optimality point as regards expenditure on consumption of data bundle or airtime saving plans by maximizing (1) subject to (3) and (4). Telecommunication airtime and data bundle is produced using capital and labour; $\mathrm{C} 0(\mathrm{t})$ and $\mathrm{y}(\mathrm{t})$ respectively according to constant returns to scale technology represented by the following production function.

$$
\mathrm{O}^{0}(\mathrm{t})=\mathrm{C}^{0}(\mathrm{t})^{\alpha} \mathrm{y}(\mathrm{t})^{1-\alpha}
$$

Optimal airtime and data plans are then determined by maximizing profits.

Since it is an open economy, household have access to information, social media, international best practices, tariff plans and markets. Therefore the equilibrium capital labour ratio is given as

$$
\begin{gathered}
C^{0}(t)=C^{0}(t) / y(t) \text { is expressed as } \\
C^{0}(t)=[\alpha /(r+\delta)]^{\alpha /(1-\alpha)}
\end{gathered}
$$

Hence, output per worker is given by

$$
\mathrm{O}^{0}(\mathrm{t})=[\alpha /(\mathrm{r}+\delta)]^{\alpha /(1-\alpha)}
$$

From (8) we propose that during the pre GSM period, households growth did not exert influence on telecommunication contribution labour productivity.

\section{Nigeria's economy in a post GSM telecommunication period}

Let's assume that in the post GSM period, $t=t^{*}$, the economy experiences an unprecedented expansion due to access to new means of production and wealth creation especially online commence, which is more productive than the pre GSM period. As a result, this post GSM economy produces $\mathrm{O}^{\mathrm{GSM}}$ of the same goods and services as produced in the pre GSM period using $\mathrm{C}^{\mathrm{GSM}}$ and new skilled worker $\mathrm{w}(\mathrm{t})$ according to a constant return to scale technology represented by the production function

Where

$$
\mathrm{O}^{\mathrm{GSM}}(\mathrm{t})=\mathrm{C}^{\mathrm{GSM}}(\mathrm{t})^{\alpha}[(1+\mathrm{r}) \mathrm{w}(\mathrm{t})]^{(1-\alpha)}
$$

$$
r>0
$$

which fully captures the advancement ushered in by GSM telecommunication revolution using new skilled labour in the new technology relative to using the old skilled labour, $y(t)$. A typical firm in the post GSM has a choice between using pre GSM or post GSM telecommunication subject to constraint in a bid to maximize profit

$$
\mathrm{O}^{0}(\mathrm{t})+\mathrm{O}^{\mathrm{GSM}}(\mathrm{t})-\mathrm{S}^{0}(\mathrm{t}) \mathrm{C}^{0}(\mathrm{t})-\mathrm{R}^{0}(\mathrm{t}) \mathrm{y}^{0}(\mathrm{t})-\mathrm{S}^{\mathrm{GSM}}(\mathrm{t}) \mathrm{C}^{\mathrm{GSM}}(\mathrm{t})-\mathrm{W}^{\mathrm{GSM}}(\mathrm{t}) \mathrm{W}^{0}(\mathrm{t})
$$

The advent of GSM telecommunication enables households to enhance their decision though their preferences which remains unchanged. For instance, household must make a choice either to work in pre GSM telecommunication oriented firms or upgrade or undertake a training to develop their capacity to enable them adapt in the new working environment in order to match industry expectation. It is assumed that labour-in-training or undergoing capacity development is unproductive. Secondly, new entrants (presumably young Nigerians) come into the market with skill sets proportional to the older individuals in the workplace will be unproductive as well. Therefore a steady state effect of population growth has been neutralized or eliminated. Thirdly, this process is not internalized by the household but plays out at an aggregate level. Where $\boldsymbol{\rho}>0$ for individuals in upgrade/training/capacity development are having an instantaneous probability of acquiring new skill set.

This evolution is captured thus:

$$
\mathrm{w}(\mathrm{t})=\mathrm{pu}(\mathrm{t})+\mathrm{nw}(\mathrm{t}) \mathrm{y}(\mathrm{t})
$$

Where

$\mathrm{U}(\mathrm{t})$ is the number of individual upgrading their skills/capacity

$\mathrm{W}(\mathrm{t})$ is the proportion of new skilled individuals in the population

$$
\mathrm{W}(\mathrm{t})=\mathrm{w}(\mathrm{t}) / \mathrm{y}(\mathrm{t})
$$


The balance $y(t)-u(t)-w(t)$ workers are engaged in firms deploying pre GSM telecommunication technology.

The main assumption concerning the post GSM skills with its associated upgrade requirement is that pr $>\mathrm{x}$

Since the effect of skill upgrade automatically translates to marginal increase in labour productivity by $r$ with a probability of $\mathrm{p}$ the condition specifies that the expected discounted gain ( $\mathrm{pr} / \mathrm{x}$ ) is greater than the short run reservation cost. This guarantees a complete switch to the post GSM technology in the short run.

By observation, even with the prevalence of GSM enabled telecommunication, the old capital simply evolves as specified in (6) and the rate of acceleration for the post GSM revolutionary telecommunication technologies is given by

$$
\mathrm{C}^{\mathrm{GSM}}(\mathrm{t})=\mathrm{V}^{\mathrm{GSM}}(\mathrm{t})-\delta \mathrm{C}^{\mathrm{GSM}}(\mathrm{t})
$$

Investment $\mathrm{V}^{\mathrm{GSM}}(\mathrm{t})$ must be greater than zero

As a result household's budget constraint now becomes

$$
\mathrm{T}(\mathrm{t})+\mathrm{k}(\mathrm{t}) \mathrm{y}(\mathrm{t})+\mathrm{V}^{\mathrm{GSM}}(\mathrm{t})+\mathrm{V}^{0}(\mathrm{t})=\mathrm{xT}(\mathrm{t})+\mathrm{R}^{0}(\mathrm{t})[\mathrm{y}(\mathrm{t})-\mathrm{w}(\mathrm{t})]+\mathrm{W}^{\mathrm{GSM}}(\mathrm{t}) \mathrm{W}(\mathrm{t})+\mathrm{S}(\mathrm{t}) \mathrm{C}(\mathrm{t})+\mathrm{S}^{\mathrm{GSM}}(\mathrm{t}) \mathrm{C}^{\mathrm{GSM}}(\mathrm{t}) 14
$$

Each household determines its plan by maximizing (1) subject to (6), (12), (13) and (14) Given that typical household faces constant interest rate on capital, allocating time between training and working can be optimized using

Subject to

$$
\operatorname{Max} \mathrm{U}(\mathrm{t}) \mathrm{S}(\mathrm{t})_{\mathrm{i}=\mathrm{t}} \int_{t *}^{\infty} e^{-(x-n)(t-t *)}\left[\mathrm{R}^{0}(\mathrm{t})\left(1+\mathrm{U}(\mathrm{t})-\mathrm{S}(\mathrm{t})+\mathrm{R}^{\mathrm{GSM}}(\mathrm{t}) \mathrm{S}(\mathrm{t})\right] \mathrm{dt} \quad 15\right.
$$

$\mathrm{S}(\mathrm{t})=\mathrm{pu}(\mathrm{t})+\mathrm{nw}(\mathrm{t})-\mathrm{nw}(\mathrm{t})$

Where $w^{\prime}(t)$ is given

The first order conditions are:

$\mathrm{R}^{0}(\mathrm{t})=\mathrm{p} \mu(\mathrm{t})$

$\mu(\mathrm{t})=-\left[\mathrm{R}^{\mathrm{GSM}}(\mathrm{t})\right]-\mathrm{R}^{0}(\mathrm{t})+\mathrm{x} \mu(\mathrm{t})$

$\lim _{t \rightarrow \infty} \mu(\mathrm{t}) \mathrm{w}(\mathrm{t}) e^{-(x-n)(t-t *)}=0$

Where $\mu(\mathrm{t})$ is the anticipated income associated with being a GSM telecom skilled worker. Since this new capital stock can be financed on the market at rate $\mathrm{x}+\delta$, it therefore shows capital-labour ratio in the post GSM telecommunication oriented or dominated era and wage rate are constant.

Wage paid to GSM telecommunication complaint workers is

$$
\mathrm{R}^{\mathrm{GSM}}(\mathrm{t})=(1-\alpha)(1+\gamma)\left[\alpha /(\mathrm{x}+\delta)^{\alpha /(1-\alpha)}\right.
$$

It can be shown that in a co-state scenario, wage paid pre GSM technology firm is

$$
\mathrm{R}^{0}(\mathrm{t})=\mathrm{p} /(\mathrm{x}+\mathrm{p}) \mathrm{R}^{\mathrm{GSM}}(\mathrm{t})
$$

Since $\mathrm{R}^{0}(\mathrm{t})$ equals the marginal productivity of labour in pre GSM telecommunication era, therefore the fraction of individual in capacity development is

$$
\mu(\mathrm{t})=1-\mathrm{w}(\mathrm{t})-[\mathrm{x}+\mathrm{p} / \mathrm{p}(1+\mathrm{r})]^{1 / \alpha}[(\mathrm{x}+\delta) / \alpha]^{1 / 1-\alpha} \mathrm{C}^{0}(\mathrm{t})
$$

By this assumption that $\mathrm{pr}>\mathrm{x}$ which implies that in equilibrium, the marginal efficiency of capital in the pre GSM telecommunication era is lower that the post GSM era, hence firm will choose $V^{0}(t)=0$ after the introduction of the new telecommunication platform. As a result, the evolution of telecom compliant labour for $\left(t \geq t^{*}\right)$ is equal to

$$
\mathrm{W}(\mathrm{t})=1-\mathrm{e}^{-\mathrm{p}\left(\mathrm{t}-\mathrm{t}^{*}\right)}-\mathrm{p} /(\mathrm{p}-\delta-\mathrm{n})\left[\mathrm{x}+\mathrm{p} / \mathrm{p}(1+\mathrm{r})^{1 / \alpha}[(\mathrm{x}+\delta) / \alpha]^{1 / 1-\alpha} \mathrm{C}^{0}(\mathrm{t})\left[\mathrm{e}^{-(\delta+\mathrm{n})\left(\mathrm{t}-\mathrm{t}^{*}\right)} \mathrm{e}^{-\mathrm{p}\left(\mathrm{t}-\mathrm{t}^{*}\right)}\right] 19\right.
$$

Skill sets and capacity development exhibits a dynamism which determines the output per worker per household. The per worker evolution per time that takes place after upgrade capacity $\left(t \geq t^{*}\right)$ can be derived from the production function given by

$$
\begin{gathered}
\mathrm{O}(\mathrm{t})=(1+\gamma)\left[\alpha /(\mathrm{x}+\delta)^{\alpha / 1-\alpha}+[\mathrm{x}+\mathrm{p} / \mathrm{p}(1+\gamma)]^{1 / \alpha}(1+\gamma)(\mathrm{x}+\delta) / \alpha\left[\mathrm{p} /(\mathrm{x}+\mathrm{n})-\mathrm{P} /(\mathrm{p}-\delta-\mathrm{n}) \mathrm{C}^{0}(\mathrm{t}) \mathrm{e}^{-(\delta+\mathrm{n})\left(\mathrm{t}-\mathrm{t}^{*}\right)}\right.\right. \\
+(1+\gamma)\left[\alpha /(\mathrm{x}+\delta)^{\alpha / 1-\alpha}[\mathrm{p} /(\mathrm{p}-\delta-\mathrm{n})]\left[\mathrm{x}+\mathrm{p} / \mathrm{p}(1+\gamma)^{1 / 1-\alpha} \mathrm{C}^{0}\left(\mathrm{t}^{*}\right)^{-1} \mathrm{e}^{-\mathrm{p}\left(\mathrm{t}-\mathrm{t}^{*}\right)}\right.\right.
\end{gathered}
$$

Where $\mathrm{C}^{0}\left(\mathrm{t}^{*}\right)$ denotes the capital-labour ratio in the pre GSM telecommunication period at time $\mathrm{t}^{*}$ what then is the characteristics of the effect of the advent of GSM oriented telecommunication

From (11) to (20) we propose that emanating from steady state of the economy where only the pre GSM telecommunication existed, the introduction of the GSM telecommunication triggers a temporary drop in labour productivity. In the same vein, after the introduction of GSM telecommunication, the population/economy will first experience drop in productivity. This is so because since there are fewer workers operating with pre GSM telecommunication model, output drops. As a result, the rental rate of pre GSM telecommunication skills drops lower than the post GSM telecommunication skills. Automatically, there is no incentive for household to invest in the old capital stock. This is further exacerbated when labour opts for capacity development or upgrade or training thereby forcing productivity to dip. However, when the diffusion of GSM telecommunication skill set is widespread the trend reverses. The system of equations therefore suggests a way of finding out telecommunication paradigm shift. Notwithstanding, the key implications can be tested using a regression framework.

$\mathrm{t}<\mathrm{t}^{*}, \log \mathrm{O}(\mathrm{t})-\log \mathrm{O}(0) / \mathrm{t}=\alpha_{0 \mathrm{t}}+\alpha_{1}\left[(\log \mathrm{y}(\mathrm{t})-\log \mathrm{y}(0)] / \mathrm{t}+\alpha_{2} \mathrm{r}(\mathrm{t})+\varepsilon_{(\mathrm{t})}\right.$

and 
$\mathrm{t} \geq \mathrm{t}^{*}, \log \mathrm{O}(\mathrm{t})-\log \mathrm{O}\left(\mathrm{t}^{*}\right) / \mathrm{t}-\mathrm{t}^{*}=\beta_{0 \mathrm{t}}+\beta_{1}\left[\left(\log \mathrm{y}(\mathrm{t})-\log \mathrm{y}\left(\mathrm{t}^{*}\right)\right] / \mathrm{t}-\mathrm{t}^{*}+\beta_{2} \mathrm{r}(\mathrm{t})+\varepsilon_{(\mathrm{t})}\right.$

where $\mathrm{x}$ is set of variables explaining the phenomenon.

Let's consider an initial pre GSM telecommunication period where a good or service G can be produced using the production function

Where $0 \leq \alpha \leq 1$

$$
\mathrm{G}(\mathrm{t})=\mathrm{C}_{\mathrm{G}}{ }^{0}(\mathrm{t})^{\alpha}\left[\mathrm{Y}_{\mathrm{G}}{ }^{0}(\mathrm{t}) \mathrm{e}(\mathrm{t})\right]^{1-\alpha}
$$

$\mathrm{C}_{\mathrm{G}}{ }^{0}$ is the physical capital

$\mathrm{Y}_{\mathrm{G}}{ }^{0}$ is the labour time

$\mathrm{e}$ is effort applied

According to Beaudry et al (2005) e reacts to the degree to which the wage paid by a producer of $\mathrm{G}$ exceeds the market wage

Let competitive wage rate be $\mathrm{R}_{\mathrm{c}}(\mathrm{t})$ and $\mathrm{R}_{\mathrm{G}}^{0}(\mathrm{t})$ be the actual wage paid to a worker producing $\mathrm{G}$. The Beaudry et al (2005) condition specifies that $e$ is an increasing function of $R^{0}{ }_{G}(t) / R_{c}(t)$

Hence,

$\mathrm{e}(\mathrm{t})=\mathrm{e}\left[\mathrm{R}^{0}{ }_{\mathrm{G}}(\mathrm{t}) / \mathrm{R}_{\mathrm{c}}(\mathrm{t})\right], \mathrm{e}^{\prime}\left[\mathrm{R}^{0}{ }_{\mathrm{G}} / \mathrm{R}_{\mathrm{c}}(\mathrm{t})\right]>0$

Now since GSM telecommunication introduces an alternative means of producing $G$ which is $f\left[C^{G S M}{ }_{G}(t)\right.$, $\mathrm{Y}^{\mathrm{GSM}}{ }_{\mathrm{G}}(\mathrm{t})$ ] where $\mathrm{C}^{\mathrm{GSM}}{ }_{\mathrm{G}}$ is new type of capital. GSM telecommunication aids the reduction of physical and mental effort through increased automation and processing speed. Hence firm will pay workers $R_{G}^{0}(t)$ instead of $R_{c}(t)$ thereby investing the difference in constant upgrade of telecommunication equipment and software to boost efficiency via automation and processing speed. At firm and household level, GSM telecommunication makes task accomplishment easier.

\section{Conclusion}

The main objective of the paper has been to mathematically explain the economics of employment dynamics, capacity development and link it to household telecommunication expenditure in Nigeria. The system of equations deployed served this purpose. It helped surgically and scientifically discuss the subject matter without sociocultural or political bias since Nigeria is a melting pot of diverse backgrounds. In this treatise employment dynamics, capacity development, telecommunication diffusion interacts with the rate at which the new technology impacts them in a continuum.

These mathematical and logical manipulations with the aid of theoretical economic foundations have given rise to some policy discussion. Since GSM telecommunication has become the ultimate disruptor, enhancing lifestyle, it is arguably the key to fix the mismatch between job market realities, workers skill set and capacity. The article proposes that since youth, job creators or seekers emanate from households defined by myriad sociocultural affinities, combating youth unemployment ravaging Nigeria would require merit based system devoid of the limitations, conflicts and constraints inherent in our socio-political and cultural backgrounds. Difficult as it may be entrepreneurship and its success is possible because it is a purely competitive model based on merit, driven by innovation as demonstrated by mathematics and logic.

To increase productivity, youth employment opportunities, capacity development also known as training , skill set upgrade, by taking advantage of the market, more research on the subject matter will lead us to provide a more definite answer because Nigeria's and indeed Africa's growth potential is locked in its private sector.

Finally, to combat this crisis, the Nigerian and indeed African governments and private sector institutions must as a matter of urgency nurture innovation initiatives and offer incentives for individuals and businesses to be more creative, such as research and development (R\&D) funding and intellectual property rights. The motivation is that in a knowledge-based economy, the spillover effects from investment in GSM telecommunication and people will keep generating returns. Examples are GSM telecommunications hardware and software, and other high-tech industries, play a particularly important role here.

\section{References}

Adeneye, O. A., Otto, G and Cookey, A. E. (2014). The effect of FDI inflows on Economic Growth in Nigeria 1980-2012.West African Journal of Business and Management Science, Nigeria 3(3):1 - 7 Published by faculty of Business Administration Imo State University, Owerri Nigeria.

Adeneye, O. A, Saheed, Z. S, Alexander, A. A. and Ibrahim G.U. (2018).Rural-Urbanisation Effect On Inflationary Pressure And Unemployment In Urban Areas Of Lagos State, Nigeria. International Journal of Development and Economic Sustainability, 6(2): 20-40,

Atsu, F., Agyei, C., Darbi, W.P and Adjei-Mensah, S. (2013). The impact of telecommunication revenue on economic growth. African Journal of Economic and Management Studies, 5 (2), 195-208 Emerald Group Publishing Limited 2040-0705.DOI 10.1108/AJEMS-10-2011-0076. www.emeraldinsight.com/20400705.htm.

Beaudry, P; F. Collard. (2002) Why is employment-productivity tradeoff among industrialized countries so strong? 
NBER working paper 8754

Beaudry, P; F. Collard. (2004) Globalization, returns to accumulation and the world distribution of output: a study of the changing world distribution of output per worker. NBER working paper 10565

Beaudry, P; F. Collard; D.A. Green. (2004) Decomposing the twin peaks: a study of the changing world distribution of output per worker. NBER working paper 9240

Beaudry, P; F. Collard; D.A. Green. (2005) Demographics and recent productivity performance: insights from cross-country comparisons. Canadian Journal of Economics. 38(2), 310-342

Bresnahan, T; and M. Trajtenberg (1995) General purpose technologies: engines of growth? Journal of Econometrics 65, 83-108

Eke, C \& Aluko B (2006) "A Model of How to Grow Internet penetration in Nigeria's Rural Areas." Nigerian Journal of Social Research, NJSR. 1(2):9-22.

Eke, Chukwuemeka Ifegwu \& I. I Uke (2006) "Thriving on Chaos: A Critique of The G.S.M Mirage in Nigeria." The Abuja Management Review. Vol.4 No.2. Pp 157 - 167.

Eke, C.I. \& Mohammed, Y. (2012) The Impact of Information Communication Technology (ICT) on Nigeria's Productivity and Economic Growth. Finance and Accounting Research Monitor. Vol. 3 No. 1. Pp 134 - 145.

Eke, C.I. \& Magaji, S. (2013) Measuring the Technical Efficiency of Wired and Wireless Technologies in Nigerian Cyber Cafes. CBN Journal of Applied Statistics Vol. 4 No.1. Pp $15-35$.

Eke, C.I. (2019) Impact telecommunication contribution and teledensity has on economic growth in Nigeria, 19802018. An unpublished manuscript.

Feyrer, J. (2002) Demographics and productivity. Mimeo, Dartmouth college.

Haider, H. and Sharif, A. A. (2016). Impact of Teledensity on Economic Growth: A Comparative Analysis of South Asian Countries. International Journal of Economics and Empirical Research. 4(11), 571-581.

Harris, R. and Sollis, R. (2003). Applied Time Series Modelling and Forecasting, Wiley, West Sussex.

Helpman, E; and T. Trajtenberg (1998) A tiem to sow and a time to reap: growth based on general purpose technologies. In General Purpose Technologies and Economic Growth, ed. E. Helpmann (Cambridge MA: MIT press)

James,C.(2019). What is the Consumer Price Index (CPI)? Trading \& Investing Content at Investopedia and former Head of Research at Gain Capital (NYSE: GCAP) https://www.investopedia.com/contributors/101529/.

Jhingan, M.L. (2010). Economic Development, New Delhi, Vrinda Publications (P) Ltd

Johansen, S. (1991). Estimation and Hypothesis Testing of Cointegration Vectors in Gaussian Vector Autoregressive Models, Econometrica, 59(),1551-1580.

Johansen, S. and Juselius, K. (1990). Maximum Likelihood Estimation and Inference on Cointegration-with Applications to the Demand for Money, Oxford Bulletin of Economics and Statistics, 52,(), 169-210.

Keynes, John Maynard. (1936). The General Theory of Employment, Interest, and Money. Quarterly Journal of Economics, 51(2):209-223.

Mamoun, M.M and Talib, M.W.(2017).The Impact of Telecom Infrastructure on the Economic Growth: The Case of Oil-producing and Non-Oil Producing Arab Countries. International Journal of Economics and Financial Issues, 7(3), 423-428 ISSN: 2146-4138 http: www.econjournals.com.

Mankiw, N. G. (2011). Measure of Inflation .Principles of Economics (6th ed.). Cengage Learning. ISBN 978-0538-45305-9

Mohammed,Y; Okoroafor, O.K. and Awe, E.O.(2015). Analysis of the relationship between inflation, unemployment and economic growth in Nigeria: 1987-2012. Applied economics and finance,2(3); August2015 ISSN 2332-7294 E-ISSN 2332-7308 Published by Redfame PublishingURL: http://aef.redfame.com

Pesaran, M.H., Shin, Y. and Smith, R.J. (2001). Bounds Testing Approaches to the Analysis of Level Relationships, Journal of Applied Econometrics, 16,(3), 289 - 326.

Raman, K.(2015). Basic concepts in telecommunications systems. Journal of Telecommunications System \& Management, 4(1):10.4172/2167-0919.1000e116.

Romm, C. and Clarke, R.J., (1995), Virtual communities research themes: A preliminary draft for a comprehensive model, Australian Conference in Information Systems'95, Perth, Australia, 57-66

Romer, P.M. (1990) Endogenous technological change. Journal of Political Economy (98) 71-102

Schumpeter, J.A. 1942. Capitalism, Socialism and Democracy. New York: Harper

Sproull, L., and Faraj, S., (1997), Atheism, sex, and databases: the net as a social technology, in Culture of the Internet Ed. Kiesler, S., Lawrence Eribaum Associates, Mahwah, New Jersey

Sridhar, K and Sridhar, V. (2014). Telecommunications Infrastructure and Economic Growth: Evidence from Developing Countries. National Institute of Public Finance and Policy, Working Papers. 7.

Sulaiman, C. (2013). Assessing the impact of GSM sub-telecommunication sector on the Teledensity Rate and Economic Growth in Nigeria: Time Series Analysis. International Journal of Business and Social Science, 4(3); 
Tahir, M, Amjid, A., Noureen ,A., Muhammad, I., Sadia, Q., Hafiz Zafar, N., Nasir, A and Iram, S .(2014).Determinants of unemployment in Pakistan: A statistical study. International Journal of Asian Social Science,4(12): 1163-1175

Ugur, M. (2016) Modeling Growth: Exogenous, endogenous and Schumpeterian growth

models. Greenwich papers in political economy. Retrieved August 14, 2019 from https://gala.gre.ac.uk/id/eprint/14665/1/GPERC37_MU.pdf

Uwakaeme, S.O.(2015).Economic growth in Nigeria: An empirical investigation of determinants and causal relationship (1980 - 2012). American journal of economics, 5(1): 9-20

Wellman, B., (1997), An electronic group is virtually a social network, in Culture andthe Internet, Ed. Kiesler, S., Lawrence Eribaum Associates, Mahwah, New Jerse

Wilde, W. D. and Swatman, P. A., (1997), Towards Virtual Communities in RuralAustralia, International Journal of Electronic Commerce, 2(1)

World Bank (2018). World Development Indicators, Washington D.C. Data: Agriculture, value added (constant 2010 USD). Available online: http://data.worldbank.org/indicator

World Factbook, U.S. Central Intelligence Agency.(2014). Retrieved 21 February 2014.

Zhong X, Zhang, C, Shi, R and Jiang H, (2019) Electricity consumption and economic growth nexus in China: an autoregressive distributed lag approach. Environment Science Pollution Research International; 26(14):14627-14637 doi: 10.1007/s11356-019-04699-w. Epub 2019 Mar 15 